\title{
How Does Social Media Influence College Students to Recognize Entrepreneurial Opportunities? - Evidence from China
}

\author{
Eunyoung Nam ${ }^{1}$, Peng Xiong ${ }^{2}$ \\ ${ }^{1}$ College of Business Administration, Sejong University, Seoul 05006, Korea \\ ${ }^{2}$ Graduate School of Management of Technology, Pukyong National University, Busan 48547, Korea \\ Correspondence: Peng Xiong, Graduate School of Management of Technology, Pukyong National University, Busan \\ 48547, Korea.
}

Received: November 5, 2021

Accepted: November 20, 2021

Online Published: November 21, 2021

doi:10.11114/smc.v9i2.5405

URL: https://doi.org/10.11114/smc.v9i2.5405

\begin{abstract}
The rapid development of information technology is having a profound impact on college students' entrepreneurial behavior,and accurately recognize entrepreneurial opportunities will affect the success or failure of individual entrepreneurship. The purpose of this study is to explore if and how social media influences college students to recognize entrepreneurial opportunities. A systematic review of relevant research results including social media in the field of entrepreneurship, entrepreneurship of college students, etc., this paper puts forward five dimensions and six hypotheses, including entrepreneurial alertness, priori knowledge, social capital, entrepreneurial opportunity recognition, and social media. A total of 508 valid questionnaires were obtained by designing questionnaires, organizing surveys, and screening data for college students. Through the reliability and validity test, correlation analysis, and hypothesis test analysis of the returned questionnaire data, all six hypotheses were verified. The empirical analysis shows that social media can significantly affect the recognition of entrepreneurial opportunities for college entrepreneurs. priori knowledge and entrepreneurial alertness play a mediating role and a moderating role respectively in this process. Meanwhile, priori knowledge plays a significant positive role in promoting entrepreneurial vigilance. Social capital has a direct and positive impact on college students' entrepreneurial opportunity recognition, and plays a moderating role in the impact of social media on college students' entrepreneurial opportunity recognition.
\end{abstract}

Keywords: social media, entrepreneurial opportunity recognition, entrepreneurial alertness, priori knowledge, social capital, entrepreneurship education

\section{Introduction}

The essence of entrepreneurship is the recognition and development of entrepreneurial opportunities, so entrepreneurial opportunities occupy an important position in entrepreneurial research, which can be traced back to the time of Schumpeter(Schumpeter, 1934). As much as possible in order to accurately and fully explain why some people are able to identify entrepreneurial opportunities and others can't identify, scholars have done a lot of theoretical and empirical research, the definition of entrepreneurial opportunities, identify business opportunities of the key factors analysis experience and start-up performance, entrepreneurs produced a series of research results. As a very important group of potential entrepreneurs, college students play a prominent role in promoting regional economic growth and alleviating employment pressure. There are few studies on the factors of social media. This paper focuses on internal factors such as social media and priori knowledge and external factors such as social capital. By analyzing the data obtained from the questionnaire, it illustrates the internal influence mechanism of social media on the process of identifying entrepreneurial opportunities for college entrepreneurs.

Firstly, this paper systematically reviews the different ideas and representative viewpoints of entrepreneurial opportunity research, the role of social media in entrepreneurial opportunity recognition, and the key influencing factors of entrepreneurial opportunity recognition of college students. Then, taking college students as the research object, data is collected by a questionnaire. The analysis results show that social media has a direct and positive impact on the recognition of college students' entrepreneurial opportunities, and in this process, priori knowledge plays an intermediary role, while entrepreneurial alertness and social capital play a moderating role. This study is helpful to 
re-examine the process of college students' recognition of entrepreneurial opportunities from a multi-dimensional perspective.

\section{Literature Review}

\subsection{The Research Review of Entrepreneurial Opportunity Recognition}

The correct recognition of entrepreneurial opportunities is the cornerstone of entrepreneurial success. The research on the recognition of entrepreneurial opportunities has become a field of attention in entrepreneurial research, and its research context is deeply influenced by the two scholars---Schumpeter and Kirzner. Schumpeter believed that entrepreneurial opportunities are a recombination of resources. The new combination can not only be a product or service, but also a new production method, a new market organization method, or a new raw material. Therefore, entrepreneurial opportunities exist objectively and only need to be "discovered" (Schumpeter, 1934). Kirzner takes a different view, arguing that market needs, resources, and new ways of producing or organizing markets cannot exist in their final form in advance, but are essentially "invented" by entrepreneurs. A notable feature of such "invented" entrepreneurial opportunities is that they can compensate for market imperfections and have the potential to create economic returns (Kirzner, 1979).

Since then, many scholars have carried out targeted studies around the two different ideas of "discovery" and "invention". Among them, Shane and other scholars firmly support Schumpeter's concept of "discovery". He believes that the key to discovering entrepreneurial opportunities lies in whether one has richer priori knowledge and has stronger cognitive ability than others on this basis. These different dimensions of priori knowledge, and even genetic factors, lead individuals to identify, discover, solve, or satisfy unmet needs in the market (Aldrich \& Cliff, 2003; Cliff et al., 2006; Cooper \& Park, 2008; Shane, 2000; Ucbasaran et al., 2003). Entrepreneurs and their teams will judge the potential of entrepreneurial opportunities from multiple levels, and build a profit-sharing organization by piecing together existing resources, so as to complete the whole process of entrepreneurial opportunity recognition (Liu et al., 2019).

Baron was one of the most important proponents of the "invention" view after Kirzner. He proposed that experienced entrepreneurs have a more accurate cognitive framework and have an advantage in creating and inventing the most profitable entrepreneurial opportunities(Baron \& Ensley, 2006). Meanwhile, the acquisition of new knowledge plays a mediating role in the process of entrepreneurial opportunity recognition, and the influence of market knowledge on entrepreneurial opportunity recognition is more significant than that of technical knowledge (Sun \& Ding, 2018). In addition, emotions and positive attitudes also have a significant impact on individual creativity and thus have a positive impact on the creation of entrepreneurial opportunities by individuals(Baron \& Tang, 2011), while creativity, cognition, and uncertainty are the potential forces for individuals to seek entrepreneurial opportunities(Butler et al., 2010; Chen \& Yang, 2009).

In recent years, scholars have gradually realized that these two ideas have the characteristics of identity, because their research objects are the process of opportunity recognition, the object of concern is the entrepreneur, and the variable of explanation is the uncertainty of the process of opportunity recognition. What is different is that there are differences in the nature of the opportunity, the role of entrepreneurs, the degree of uncertainty of risk, and research perspectives in different literature. The "discovery theory" assumes that opportunities already exist in the market, which is an objectively oriented imprinting process with the characteristics of scientific discovery. It mainly studies how entrepreneurs' priori knowledge, creativity, and cognitive process promote entrepreneurial opportunity recognition from an internal perspective. However, "invention theory" is a subjectively oriented mass tracking process, which is characterized by social construction. It pays more attention to how entrepreneurs make more rational use of external resources from an external perspective, especially to seek and acquire information and knowledge through social networks, so as to create entrepreneurial opportunities more efficiently (Alvarez \& Barney, 2007; Anokhin et al., 2010; Reim et al., 2014).

In general, scholars still have different opinions on the concepts of entrepreneurial opportunity recognition, evaluation, and development, and it is still a very challenging work to establish a universally accepted research framework(Zhang $\& \mathrm{Ge}, 2014)$. This paper argues that given the different natures of the entrepreneurial opportunities, market environment, resources, organization, customer requirements), the individual has significant heterogeneity (character, genes, and even human tissue function) and is affected by many factors, both knowledge, social networks, environmental conditions, entrepreneurial alertness, social capital), inevitably leading to the process of entrepreneurial opportunity recognition is very complicated. For the study of complex problems, it is necessary to integrate the multi-dimensional perspective, which is to combine the internal factors and external factors involved in the research object (entrepreneurs) for analysis(De Carolis \& Saparito, 2006; Mary George et al., 2016). 


\subsection{A Review Of Research on the Influence of Social Media on Entrepreneurial Opportunity Recognition}

With the rapid development of information technology, various social media platforms, such as WeChat, Weibo, Douyin, and Xiaohongshu, have greatly changed the way entrepreneurs acquire information and knowledge, as well as fundamentally changed the way enterprises interact with users, the way enterprises reorganize resources and the way of product or service marketing. Existing studies focus on two aspects: the impact of social media on entrepreneurial opportunity recognition and the impact of social media on the development of entrepreneurial opportunity.

Both theoretical and empirical studies show that the entrepreneurial process is fundamentally a networked activity, and the opinions of well-known entrepreneurs spread on social media platforms have a great impact on the thinking mode and cognitive framework of potential entrepreneurs and new entrepreneurs(Wang et al., 2016). However, there is great heterogeneity in the impact of social media on entrepreneurs and their choice of social media. New entrepreneurs and experienced entrepreneurs differ in their priori knowledge, which fundamentally affects their ability to identify opportunities and respond to technological changes(Mack et al., 2016). In the process of identifying entrepreneurial opportunities, first-time entrepreneurs are more likely to be influenced by mass social media, while experienced entrepreneurs are more likely to be influenced by specific enterprises, projects, or personal information online(Motoyama et al., 2018). In the process of entrepreneurial opportunity recognition, social media plays an obvious role in obtaining peer advice, which is the largest potential resource source available to entrepreneurs outside of local networks(Kuhn et al., 2016). More importantly, social media and its ever-evolving new application functions can interact with the power of institutional entrepreneurship to create conditions for social change and the emergence of new entrepreneurial opportunities(Mohajerani et al., 2015), and fundamentally affect the accumulation of social capital by entrepreneurs(Smith et al., 2017). Empirical research based on the Chinese context shows that individuals with high human capital and social capital are more likely to identify entrepreneurial opportunities, and social capital may play a more direct and independent role in the recognition of entrepreneurial opportunities (Dong \& Zhang, 2019). Further research shows that social media interaction with the same industry or similar professional background is conducive to the recognition of homogeneous entrepreneurial opportunities, while social media interaction across industries or technology fields is conducive to the recognition of heterogeneous entrepreneurial opportunities(Yu \& $\mathrm{Li}, 2020)$.

In terms of the development of entrepreneurial opportunities, social media has had a profound impact on the way entrepreneurs and potential entrepreneurs engage and collaborate, the way information is searched and shared, and the restructuring of operational processes(Drummond et al., 2018). Many companies have integrated their business strategy with their social media platforms and have a team of professionals responsible for these platforms. Most managers believe that this can help enterprises improve business performance and discover new market opportunities(Fernandes et al., 2016). Actual cases also prove that social media can lead to sustainable changes in users' purchasing environment, including the collection of users' needs and the stimulation of their consumption intention(Reiter et al., 2017). Moreover, social media creates great opportunities for the development of business relationships, promotes the establishment and use of offline social networks by entrepreneurs, and ultimately contributes to the generation of new businesses and the improvement of existing business performance (Quinton \& Wilson, 2016). Compared with large companies, start-ups or small and medium-sized enterprises can make full use of the advantages of social media in the face of complex and rapidly changing markets to upgrade and innovate their own sales processes, especially in the face of a downturn in the existing market, which helps to develop new markets and discover new opportunities(Bocconcelli et al., 2017) .

\subsection{A Review on Entrepreneurial Opportunities Recognition for College Students}

Direct studies have shown that academic disciplines and foreign educational experience have a direct impact on college students' entrepreneurial willingness. Science, technology, engineering, and mathematics (STEM) majors have higher entrepreneurial willingness than non-STEM majors. Students with foreign education experience are more likely to become entrepreneurs than those without this. Entrepreneurship encouragement policies should be more inclined to domestic-born students who have returned home with foreign STEM professional study experience(Breznitz \& Zhang, 2019). College students with entrepreneurial experience are significantly different from those without entrepreneurial experience in entrepreneurial alertness and priori knowledge, and the former is obviously superior to the latter in all aspects. College students' entrepreneurial alertness has a significant impact on identifying entrepreneurial opportunities, and priori knowledge plays a moderating role(Wang \& $\mathrm{Lu}, 2015$ ).

The entrepreneurial process of college students is the process of reshaping their own social network. The social network promotes the recognition of entrepreneurial opportunities by providing market information and stimulating entrepreneurial willingness, and its scale and structure determine the degree of positive influence on the recognition of entrepreneurial opportunities(Wang et al., 2015). The strong connection network in college students' social capital can have a positive impact on their learning of specialized knowledge, and the comments of well-known entrepreneurs in social media can also have a positive impact on college students' entrepreneurial willingness(Dohse \& Walter, 2012). 
Online information platforms provide the vast majority of information for college students' entrepreneurs and promote the recognition of entrepreneurial opportunities and the development of college students' start-ups(Zhang et al., 2018).

Empirical studies also show that the support of the university is crucial to the success of college students' entrepreneurship, especially the full use of alumni resources, which plays a decisive role in the survival of most college students' startups(Buenstorf et al., 2016). No matter whether the entrepreneurial team of college students has rich management experience, whether they can make full use of all kinds of resources and guidance provided by the school incubator is the key to the survival of a start-up company (Blank, 2020). At the level of geographical regions, the differences in regional economic development level and individual comprehensive quality are the fundamental reasons for the difference in the entrepreneurship rate of college students in first-tier cities and other cities(Bin et al., 2018). College students in third-tier cities should pay more attention to entrepreneurial opportunities in rural areas(Huang, 2016). In the same city, college students in areas where high-tech enterprises gather, technological innovation, and intellectual property declaration are intensive have higher entrepreneurial willingness than those in other areas(Dohse \& Walter, 2012).

System of learning professional knowledge, increasing the accumulation of knowledge, to identifying entrepreneurial opportunities are still very important, while social media is filled with dropping out of school entrepreneurship and hugely successful myth buster, but a wide range of surveys, college students drop out of school entrepreneurship than graduate students have a higher success rate of entrepreneurship(Buenstorf et al., 2016). And outside of professional knowledge, interpersonal skills, and leadership ability is the core of the college students need to develop entrepreneurship(RezaeiZadeh et al., 2017), creative thinking, additive type, and self-oriented counterfactual thinking is still the key to correctly identifying entrepreneurial opportunities, while the cultivation of these thoughts takes longer and more novel teaching methods(Hao et al., 2019). Entrepreneurship education for college students to have a significant role in promoting(Ayalew \& Zeleke, 2018), the exploratory study and applied study of entrepreneurial opportunity recognition is a very important positive influence (Zhang et al., 2017), but most of the current entrepreneurship education began, needs to promote teaching plans and teaching method reform, in order to realize from "forcing the students to learn" to "students' initiative to learn" (Wang \& Yao, 2014).

\section{Hypothesis and Relationship Theory Model Construction}

Existing studies have confirmed that priori knowledge has a direct and positive impact on the recognition of entrepreneurial opportunities, but different opinions focus on the role of priori knowledge in the process of entrepreneurial opportunity recognition and the way it plays a role. Most of the early studies suggested that priori knowledge is a kind of personal cognitive resource, which is the basis of the opportunity recognition process. With the deepening of research, some scholars believe that only when the priori knowledge is combined with entrepreneurial alertness, social capital, and relationship network, can individuals more actively recognize entrepreneurial opportunities. However, further empirical tests are needed to link priori knowledge to social media, which is widely used by entrepreneurs. Priori knowledge is an important part of entrepreneurial opportunity recognition, which directly affects college students' understanding of new information. Therefore, the following hypothesis is proposed:

H1: Priori knowledge plays an intermediary role in the influence of social media on college students' entrepreneurial opportunity recognition.

The concept of entrepreneurial alertness was introduced into entrepreneurship research by(Kirzner, 1979), who defined it as "being able to notice opportunities that have hitherto been ignored". Although definitions of entrepreneurial alertness vary, scholars generally agree that entrepreneurial alertness is the most important cognitive/psychological factor in identifying entrepreneurial opportunities, a cognitive ability that entrepreneurs possess that helps them identify entrepreneurial opportunities and is a crucial first step in the entrepreneurial process.

Most of the existing research focuses on the role of alertness in the process of entrepreneurial opportunity recognition. From the perspective of the "discovery" view, the research on the cognitive mechanism related to alertness shows that college students with high entrepreneurial alertness can find opportunities even if they do not actively look for opportunities, only by observing phenomena. They are more sensitive to entrepreneurial opportunities than the average person. However, there is significant heterogeneity in individual entrepreneurial alertness. It is found that the process of seeking information and identifying opportunities are different between entrepreneurs and non-entrepreneurs. Some scholars believe that the main reasons for the difference in individual entrepreneurial alertness are priori knowledge, work experience, and environment, but there are few empirical studies on this influencing process. From the perspective of "invention", entrepreneurial vigilance is a key component of college students' entrepreneurial behavior, and it is the key to studying the entrepreneurial opportunity recognition process from the internal perspective. Most scholars agree that entrepreneurial alertness is a behavioral tendency, mainly composed of endogenous knowledge generated in the process of problem-solving. People build new knowledge over time, so startup vigilance is constantly changing. This 
view suggests that entrepreneurs must have the right knowledge if they want to create new opportunities in the market. Two hypotheses are proposed as follows:

H2: Priori knowledge has a significant positive effect on college students' entrepreneurial alertness.

H3: Entrepreneurial alertness plays a moderating role in the influence of social media on college students' entrepreneurial opportunity recognition.

Social capital is an important external influence factor for entrepreneurs to identify entrepreneurial opportunities, and it provides information and resources for entrepreneurs to identify entrepreneurial opportunities. Social media platforms offer entrepreneurs the possibility to connect with people in different fields and locations, theoretically helping entrepreneurs discover more entrepreneurial opportunities. According to the literature based on the strength of weak ties, entrepreneurs can collect more information when interacting with weak social ties compared with strong ties. This conclusion is consistent with the experience of most entrepreneurial college students, most of the time they only interact occasionally with a variety of people. Another view based on embeddedness theory holds that only strong relationship embedded ties can provide entrepreneurs with key strategic opportunities and resources. The more strong connections entrepreneurs have, the more resources and opportunities they can access and recognize. In fact, these two views are not contradictory. First-time or potential entrepreneurs (college students) benefit more from weak social ties, i.e. they are more influenced by social media. Experienced entrepreneurs, on the other hand, benefit more from strong relationships that generate information about specific businesses or projects, and are less influenced by social media. Therefore, the following hypotheses are proposed:

H4: Social capital has a direct and positive impact on the recognition of entrepreneurial opportunities for college students.

The typical feature of social media is communication and information sharing. Various application functions developed by social media allow users to develop virtual relationships, share information, and seek new ideas or better opportunities in many ways. More importantly, social media has changed the way entrepreneurs search, receive and discriminate information, subtly changing entrepreneurs' judgment of the market environment, sensitivity to change, and entrepreneurial alertness, which may greatly affect entrepreneurs' recognition of entrepreneurial opportunities. From the perspective of external networks, social networks help entrepreneurs interact with other entrepreneurs, no matter whether the interaction will change from weak to strong, and no matter whether the two parties are in the same industry or not. This information-sharing process helps both parties identify market trends and potential entrepreneurial opportunities. Therefore, the following hypotheses are proposed:

H5: Social media has a direct and positive impact on college students' entrepreneurial opportunity recognition.

H6: Social capital plays a moderating role in the influence of social media on college students' entrepreneurial opportunity recognition.

To sum up, a theoretical model of the relationship between "social media - internal and external factors - college students' entrepreneurial opportunity recognition" is constructed, as shown in Figure 1:

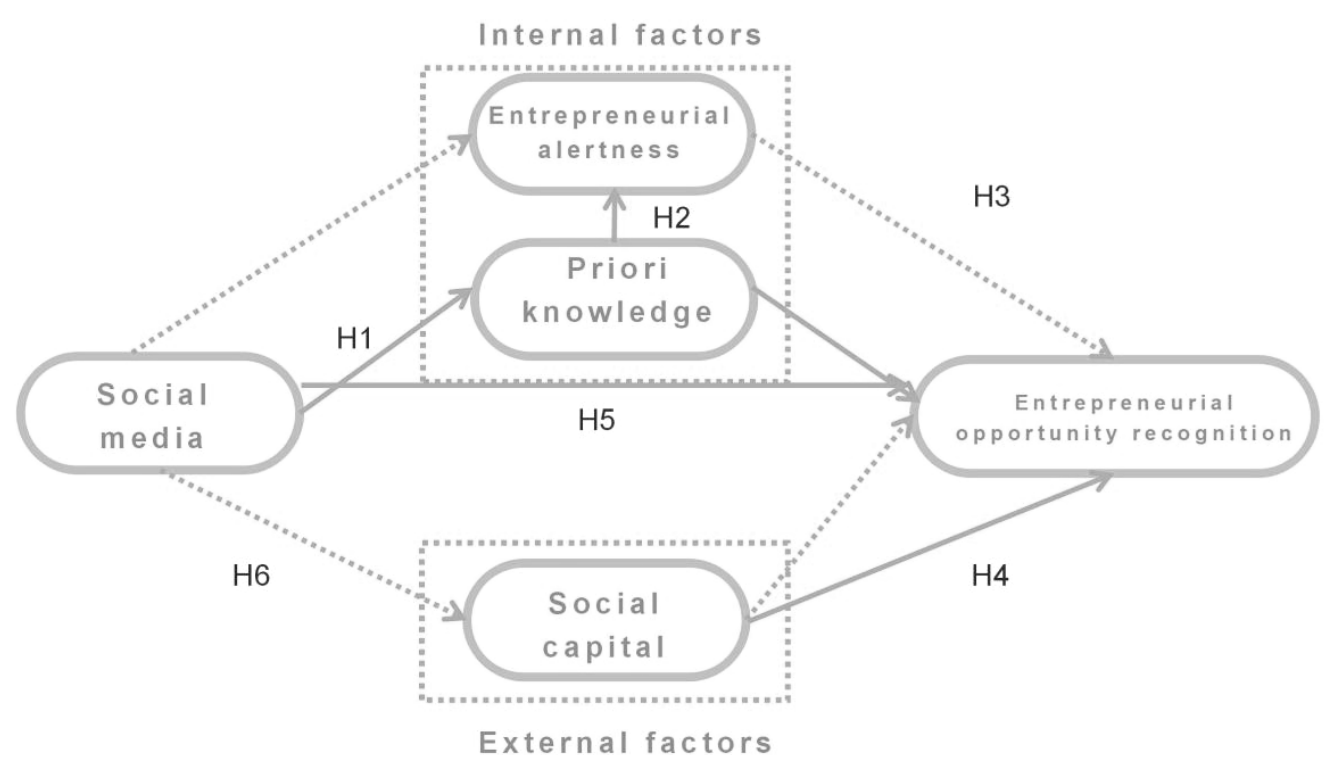

Figure. 1 Theoretical model of relationships Source: Author design 


\subsection{Research Design}

In this paper, college students as the research object, through the way of questionnaire survey, and the use of WeChat small program to generate questionnaires and collect data.

Questionnaire design. In the questionnaire, it is explained that "social media" specifically refers to network information platforms with social nature such as WeChat, Tiktok and so on.

The questionnaire is divided into two parts: open question and closed question. The open question mainly investigates the basic information of the sample, including age, gender, major (science and engineering or liberal arts), grade, interdisciplinary study experience, overseas study experience, and entrepreneurial experience. Closed questions were measured by the 5-level Likert Scale of Psychological Reaction, which is widely recognized in entrepreneurship research, with 1-5 indicating "strongly disagree, disagree, not necessarily, agree, and strongly agree". The closed questions were divided into 5 modules, namely: social media, priori knowledge, entrepreneurial alertness, social capital and entrepreneurial opportunity recognition, with a total of 30 questions.

The objects of this survey were undergraduates or postgraduates in universities in Shandong Province. A total of 600 questionnaires were issued through the WeChat mini-program, and the respondents were restricted by geographical location, IP and answer times. After removing the answers that were too random (obviously contradictory or choosing the same option for several consecutive questions) and too short (the total answer time was less than 3 minutes), a total of 508 valid questionnaires were obtained, with an effective recovery rate of $96.67 \%$. The data of open questions are shown in Table 1 below:

Table 1 Statistics of sample personal information data

\begin{tabular}{|c|c|c|c|c|c|c|c|}
\hline $\begin{array}{l}\text { The serial } \\
\text { number }\end{array}$ & Item & \multicolumn{6}{|c|}{ Percentage of data } \\
\hline \multirow{3}{*}{1} & \multirow{3}{*}{ gender } & options & \multicolumn{2}{|c|}{ male } & \multicolumn{3}{|c|}{ female } \\
\hline & & number & \multicolumn{2}{|c|}{200} & \multicolumn{3}{|c|}{308} \\
\hline & & proportion & \multicolumn{2}{|c|}{$39.37 \%$} & \multicolumn{3}{|c|}{$60.63 \%$} \\
\hline \multirow{3}{*}{2} & \multirow{3}{*}{ age } & options & $\begin{array}{c}\text { Under the } \\
18\end{array}$ & 18 to 22 & $24^{23}$ to & \multicolumn{2}{|c|}{24 or older } \\
\hline & & number & 35 & 462 & 4 & \multicolumn{2}{|r|}{7} \\
\hline & & proportion & $6.89 \%$ & $90.94 \%$ & $0.79 \%$ & \multicolumn{2}{|r|}{$1.38 \%$} \\
\hline \multirow{4}{*}{3} & \multirow{4}{*}{ professional } & options & \multicolumn{2}{|c|}{$\begin{array}{l}\text { Science and } \\
\text { Engineering }\end{array}$} & \multicolumn{3}{|c|}{ The liberal arts } \\
\hline & & number & \multicolumn{2}{|c|}{158} & \multicolumn{3}{|c|}{350} \\
\hline & & proportion & \multicolumn{2}{|c|}{$31.10 \%$} & \multicolumn{3}{|c|}{$68.90 \%$} \\
\hline & & options & freshman & sophomor & Junior year & Senior year & Graduate student \\
\hline \multirow[t]{2}{*}{4} & \multirow[t]{2}{*}{ In grade } & number & 227 & 205 & 66 & 2 & 8 \\
\hline & & proportion & $44.69 \%$ & $40.35 \%$ & $12.99 \%$ & $0.39 \%$ & $1.57 \%$ \\
\hline \multirow{3}{*}{5} & \multirow{3}{*}{$\begin{array}{c}\text { Whether interdisciplinary learning } \\
\text { experience }\end{array}$} & options & \multicolumn{2}{|c|}{ Yes } & \multirow{2}{*}{\multicolumn{3}{|c|}{$\begin{array}{l}\text { No } \\
403\end{array}$}} \\
\hline & & number & \multicolumn{2}{|c|}{105} & & & \\
\hline & & proportion & \multicolumn{2}{|c|}{$20.67 \%$} & \multicolumn{3}{|c|}{$\begin{array}{c}403 \\
79.33 \%\end{array}$} \\
\hline \multirow{3}{*}{6} & \multirow{3}{*}{ Whether the entrepreneurial experience } & options & \multirow{2}{*}{\multicolumn{2}{|c|}{ Yes }} & \multicolumn{3}{|c|}{$\begin{array}{c}19.33 \% \\
\text { No }\end{array}$} \\
\hline & & number & & & \multicolumn{3}{|c|}{240} \\
\hline & & proportion & 52. & $6 \%$ & & $47.24 \%$ & \\
\hline
\end{tabular}

\subsection{Data Processing and Results}

SPSS 20.0 software was used to test the reliability and validity of the data. Correlation analysis and confirmatory factor analysis were used to investigate the relationship between the control variables, independent variables and dependent variables. Finally, the assumptions mentioned above were verified and analyzed one by one.

3.2.1 Reliability and Validity Analysis

Table 2. KMO and Bartlett checklist

\begin{tabular}{|c|c|c|}
\hline \multicolumn{2}{|c|}{ Kaiser-Meyer-Olkin measure of sampling adequacy } & 962. \\
\hline \multirow{3}{*}{ Bartlett's test for sphericity } & The approximate chi-square & 9307.423 \\
\hline & df & 435 \\
\hline & Sig. & 000 . \\
\hline
\end{tabular}


KMO measurement value of KMO test and Bartlett test is 0.962, greater than 0.7, indicating that the questionnaire is very suitable for factor analysis. CR values are all greater than 0.7 and AVE values are all greater than 0.6. The fitting values of the model test all meet the requirements, indicating that the questionnaire samples have good reliability and validity.

Table 3. Reliability test and confirmatory factor analysis of each variable

\begin{tabular}{|c|c|c|c|c|c|}
\hline The module & $\begin{array}{l}\text { The serial } \\
\text { number }\end{array}$ & Item & $\begin{array}{l}\text { Factor } \\
\text { loading }\end{array}$ & $\mathrm{CR}$ & AVE \\
\hline \multirow{8}{*}{$\begin{array}{l}\text { social } \\
\text { media }\end{array}$} & 1 & It's easy for me to use social media & 0.8047 & \multirow{6}{*}{0.853} & \multirow{6}{*}{0.759} \\
\hline & 2 & $\begin{array}{c}\text { Social media allows me to learn a lot of new } \\
\text { information }\end{array}$ & 0.6670 & & \\
\hline & 3 & $\begin{array}{c}\text { Social media allows me to meet many new } \\
\text { friends }\end{array}$ & 0.7729 & & \\
\hline & 4 & $\begin{array}{c}\text { Social media can improve my efficiency of } \\
\text { learning new knowledge }\end{array}$ & 0.7115 & & \\
\hline & 5 & $\begin{array}{l}\text { I believe I can find my future business partners } \\
\text { through social media }\end{array}$ & 0.8380 & & \\
\hline & 6 & $\begin{array}{l}\text { When I use social media, I suddenly come up } \\
\text { with ideas for startups }\end{array}$ & 0.7606 & & \\
\hline & 7 & $\begin{array}{l}\text { I can quickly and easily store information } \\
\text { related to my major in my mind }\end{array}$ & 0.8214 & \multirow{5}{*}{0.872} & \multirow{5}{*}{0.752} \\
\hline & 8 & I have a wide range of knowledge & 0.8498 & & \\
\hline \multirow[t]{4}{*}{ priori knowledge } & 9 & $\begin{array}{l}\text { I can learn from my mistakes in learning and } \\
\text { working }\end{array}$ & 0.6371 & & \\
\hline & 10 & $\begin{array}{l}\text { I will pay more attention to social media related } \\
\text { to my major }\end{array}$ & 0.7242 & & \\
\hline & 11 & $\begin{array}{c}\text { Social media feeds related to my major give me } \\
\text { ideas for startups }\end{array}$ & 0.7275 & & \\
\hline & 12 & $\begin{array}{c}\text { I look at the problem in a different way than } \\
\text { others }\end{array}$ & 0.8106 & \multirow{3}{*}{0.712} & \multirow{3}{*}{0.813} \\
\hline \multirow[t]{6}{*}{ Entrepreneurial alertness } & 13 & $\begin{array}{l}\text { I can see connections between unrelated } \\
\text { information }\end{array}$ & 0.7758 & & \\
\hline & $\begin{array}{l}14 \\
15\end{array}$ & $\begin{array}{l}\text { I'm sensitive to opportunities to make money } \\
\text { I hesitate when faced with many big choices }\end{array}$ & $\begin{array}{l}0.8197 \\
0.8478\end{array}$ & & \\
\hline & 16 & $\begin{array}{c}\text { I am particularly interested in the development } \\
\text { of a certain industry }\end{array}$ & 0.7187 & \multirow{8}{*}{0.899} & \multirow{8}{*}{0.612} \\
\hline & 17 & I would like to know more friends & 0.6624 & & \\
\hline & 18 & $\begin{array}{l}\text { I will invite old and new friends to participate in } \\
\text { the activities I organize }\end{array}$ & 0.7006 & & \\
\hline & 19 & $\begin{array}{l}\text { I can understand other people's thoughts and } \\
\text { feelings very well }\end{array}$ & 0.7309 & & \\
\hline \multirow[t]{7}{*}{ Social capital } & 20 & $\begin{array}{l}\text { I am always willing to help a friend to get what } \\
\text { he or she wants }\end{array}$ & 0.7131 & & \\
\hline & 21 & $\begin{array}{l}\text { When I have a disagreement with my partner, I } \\
\text { will be flexible to find a compromise }\end{array}$ & 0.6892 & & \\
\hline & 22 & $\begin{array}{c}\text { I know which partners I can trust and which I } \\
\text { can't }\end{array}$ & 0.6993 & & \\
\hline & 23 & $\begin{array}{l}\text { I can allocate my time and energy to different } \\
\text { partners }\end{array}$ & 0.6735 & & \\
\hline & 24 & $\begin{array}{l}\text { I see deficiencies in the products, services or } \\
\text { sales that I deal with in my daily life }\end{array}$ & 0.7224 & \multirow{7}{*}{0.915} & \multirow{7}{*}{0.754} \\
\hline & 25 & $\begin{array}{l}\text { I will suddenly think of another entrepreneurial } \\
\text { opportunity when I think of an entrepreneurial } \\
\text { idea }\end{array}$ & 0.7662 & & \\
\hline & 26 & $\begin{array}{c}\text { I actively search for information when I have an } \\
\text { idea for a business }\end{array}$ & 0.6717 & & \\
\hline \multirow[t]{4}{*}{$\begin{array}{l}\text { Entrepreneurial } \\
\text { opportunity recognition }\end{array}$} & 27 & $\begin{array}{c}\text { Some startup ideas that I came up with are from } \\
\text { different industries }\end{array}$ & 0.7693 & & \\
\hline & 28 & $\begin{array}{c}\text { I can think of some new uses for the product } \\
\text { being used }\end{array}$ & 0.7656 & & \\
\hline & 29 & $\begin{array}{l}\text { The ideas I come up with are related to my } \\
\text { major }\end{array}$ & 0.8113 & & \\
\hline & 30 & $\begin{array}{c}\text { I think entrepreneurial opportunities are } \\
\text { everywhere in my life }\end{array}$ & 0.7732 & & \\
\hline
\end{tabular}




\subsubsection{Correlation Analysis}

The correlation between the variables is analyzed, and the results are shown in Table 4 below. The correlation coefficients among the variables are all less than 0.7 , indicating that the correlation between the variables is not high, and further regression analysis can be carried out.

Table 4. Correlation analysis

\begin{tabular}{|c|c|c|c|c|c|c|}
\hline & & $\begin{array}{l}\text { Social } \\
\text { media }\end{array}$ & $\begin{array}{c}\text { priori } \\
\text { knowledge }\end{array}$ & $\begin{array}{l}\text { Entrepreneurial } \\
\text { alertness }\end{array}$ & $\begin{array}{l}\text { Social } \\
\text { capital }\end{array}$ & $\begin{array}{l}\text { Entrepreneurial } \\
\text { opportunity } \\
\text { recognition } \\
\end{array}$ \\
\hline \multirow[t]{2}{*}{ Social media } & Pearson & 1 & $384^{* *}$ & $198{ }^{* *}$ & $300^{* *}$ & $279^{* *}$ \\
\hline & $\begin{array}{l}\text { Significance } \\
\text { (unilateral) }\end{array}$ & & 000. & 000. & 000. & 000. \\
\hline \multirow[t]{2}{*}{ Existing knowledge } & $\begin{array}{l}\text { Pearson } \\
\text { correlation }\end{array}$ & $384 .^{* *}$ & 1 & $449 .^{* *}$ & $449 .^{* *}$ & $497 .^{* *}$ \\
\hline & $\begin{array}{l}\text { Significance } \\
\text { (unilateral) }\end{array}$ & 000. & & 000. & 000. & 000. \\
\hline \multirow[t]{2}{*}{$\begin{array}{l}\text { Entrepreneurial } \\
\text { alertness }\end{array}$} & $\begin{array}{l}\text { Pearson } \\
\text { correlation }\end{array}$ & $198 .^{* *}$ & $449 .^{* *}$ & 1 & $392 .^{* *}$ & $450 .^{* *}$ \\
\hline & $\begin{array}{l}\text { Significance } \\
\text { (unilateral) }\end{array}$ & 000. & 000 & & 000. & 000. \\
\hline \multirow[t]{2}{*}{ Social capital } & $\begin{array}{l}\text { Pearson } \\
\text { correlation }\end{array}$ & $300 .^{* *}$ & $449 .^{* *}$ & $392 .^{* *}$ & 1 & $423 .^{* *}$ \\
\hline & $\begin{array}{l}\text { Significance } \\
\text { (unilateral) }\end{array}$ & 000. & 000 & 000. & & 000. \\
\hline \multirow{2}{*}{$\begin{array}{l}\text { Entrepreneurial } \\
\text { opportunity } \\
\text { recognition }\end{array}$} & $\begin{array}{l}\text { Pearson } \\
\text { correlation }\end{array}$ & $279 .^{* *}$ & $497 .^{* *}$ & $450 .^{* *}$ & $423 .^{* *}$ & 1 \\
\hline & $\begin{array}{l}\text { Significance } \\
\text { (unilateral). }\end{array}$ & 000. & 000 & 000. & 000. & \\
\hline
\end{tabular}

Hypothesis H1-H6 was verified by Bootstrap mediation method, and the results are shown in Table 5 below:

Table 5. Hypothesis verification results table

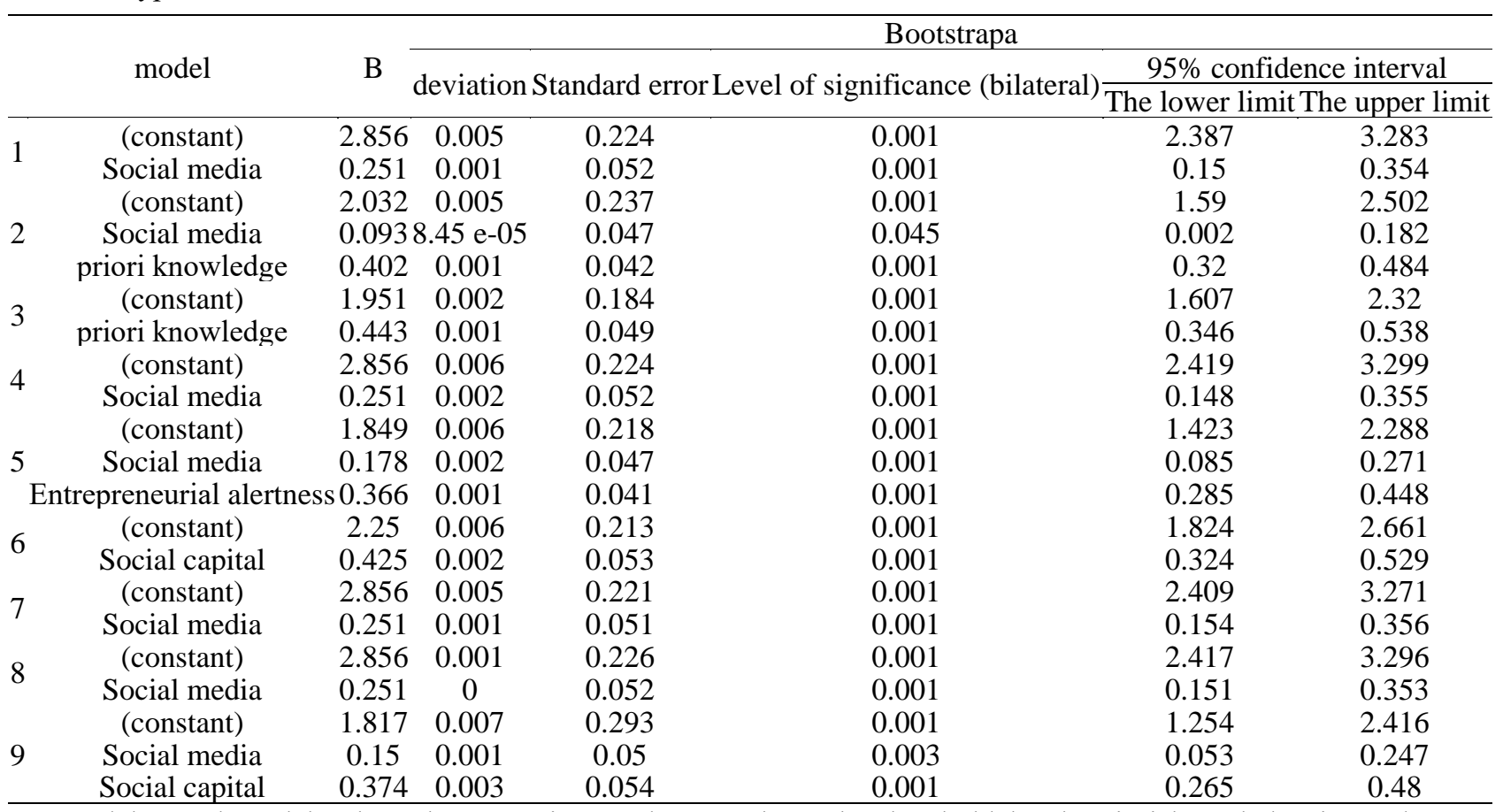

H1 model 1 and model 2 hypotheses testing, under 5\% chose the threshold level, priori knowledge is used as an intermediary variable to verify the influence of social media on the recognition of college students' entrepreneurial opportunities. The results show that the coefficient of social media's influence on the recognition of college students' entrepreneurial opportunities is 0.093 , intermediary variable coefficient is 0.402 , The significance level is less than 0.05 , indicating that the significance test has been passed, and the hypothesis $\mathrm{H} 1$ is established. That is, priori knowledge 
plays an intermediary role in the influence of social media on college students' entrepreneurial opportunity recognition.

Use model 3 to test hypothesis $\mathrm{H} 2$, test results also can be seen that priori knowledge on college students' entrepreneurial alertness influence coefficient is 0.443 , a value of 0.001 significant level, less than 0.05 threshold, shows that passing the test of significance. It confirms the hypothesis $\mathrm{H} 2$ that priori knowledge has a significant positive effect on college students' entrepreneurial alertness.

Use Model 4 and Model 5 to test the hypothesis H3, it can be seen that under the adjustment of entrepreneurial alertness, the influence coefficient of social media on the recognition of college students' entrepreneurial opportunities is 0.178 , and significant coefficient is 0.001 , less than $5 \%$ threshold, passed the test of significance, shows that entrepreneurial alertness in social media plays a moderating role on college students' entrepreneurial opportunity recognition, hypothesis $\mathrm{H} 3$ is true.

Model 6 is used to test hypothesis H4. From the test results, it can be seen that social capital has a direct impact on the recognition of entrepreneurial opportunities for college students, and the influence coefficient is 0.425 , which is significant at the level of 5\%. This proves that hypothesis $\mathrm{H} 4$ is true, that is, social capital has a direct and positive impact on the recognition of entrepreneurial opportunities for college students.

Model 7 is used to test hypothesis H5, and the results show that social media has a significant impact on college students' entrepreneurial opportunity recognition with an impact coefficient of 0.251 , which proves that hypothesis H5 is true. That is, social media has a direct and positive impact on college students' entrepreneurial opportunity recognition.

Hypothesis H6 is tested by Model 8 and Model 9. The test results show that social capital plays a moderating role in social media on college students' entrepreneurial opportunity recognition, and the influence is significant, which proves that hypothesis $\mathrm{H6}$ is true. That is, social capital plays a moderating role in the influence of social media on college students' entrepreneurial opportunity recognition.

\subsection{Analysis and Discussion}

The proportion of demographic characteristics, professional knowledge and entrepreneurial experience of the data sample is reasonable, the reliability and validity of the sample data are good, and the correlation between the variables is not high. The analysis of sample data proves that the six hypotheses are true. The results show that social media in college students' entrepreneurship has played an important role in the process of opportunity recognition, changed the way students entrepreneurs access information and search, and further influenced their way of thinking, decision making. Finally, it has a direct and positive impact on the recognition of entrepreneurial opportunities. However, this effect has strong heterogeneity. priori knowledge, entrepreneurial vigilance and social capital all play an important role in this process.

Priori knowledge is the key influencing factor of entrepreneurial opportunity recognition and plays a mediating role in the influencing process of entrepreneurial opportunity recognition of college students. The cognitive framework formed based on priori knowledge directly affects the understanding of college students' entrepreneurs on technological innovation and market demand, and enhances their entrepreneurial alertness in the same field of knowledge. Entrepreneurs with different priori knowledge backgrounds choose and are influenced by social media to different degrees, which ultimately affects their recognition of entrepreneurial opportunities.

Entrepreneurship alertness plays a moderating role in the impact of social media on college students' entrepreneurial opportunity recognition. Firt-time entrepreneurs with low entrepreneurial alertness are more likely to be influenced by popular social media. For example, lectures, videos and related speeches of various well-known entrepreneurs and entrepreneurs have a greater impact on the cognitive framework of first-time entrepreneurs. Experienced entrepreneurs generally select media information that they are interested in or engaged in, and specific enterprise, project or personal information on social media has a greater impact on them.

Social capital is the key external factor for college students to identify entrepreneurial opportunities. It not only provides information and resources for college students in the process of identifying entrepreneurial opportunities, but also provides a way to obtain scarce resources. Therefore, social capital has a direct and positive impact on college students' entrepreneurial opportunity recognition, and plays a moderating role in the impact of social media on college students' entrepreneurial opportunity recognition. Individuals with high human capital and social capital are more likely to identify entrepreneurial opportunities. The process of identifying and developing entrepreneurial opportunities for college students is also a process of reshaping their own social capital. The scale and structure of access to social capital affect entrepreneurial willingness and their recognition of entrepreneurial opportunities. 


\section{Conclusion}

This paper aims to examine the impact of social media on college students, the largest group of potential entrepreneurs, in the process of entrepreneurial opportunity recognition. Scholars have conducted in-depth analysis on the two viewpoints of "discovery" and "invention". Since the category and recognition process of entrepreneurial opportunities involves many influencing factors, the process of identifying entrepreneurial opportunities is very complex and has significant heterogeneity. It is still a huge challenge to establish a widely accepted research framework for entrepreneurial opportunities. This paper attempts to study this complex problem and conduct a convergent analysis from a multi-dimensional perspective.

In this paper, the research of social media in entrepreneurial opportunity recognition, combined with the college students' entrepreneurship research, extracting the influence of social media in the key internal factors in the process of college students' entrepreneurial opportunity recognition (entrepreneurial alertness and priori knowledge), and the key external factors (social capital), at the same time puts forward the corresponding assumptions.

The results of the empirical analysis in this paper confirm the significant influence of social media on the recognition of entrepreneurial opportunities for college students, and reveal that both internal and external factors play their respective roles in the recognition of entrepreneurial opportunities, and it is inappropriate to overemphasize the decisive role of a single factor.

The analysis results provide enlightenment for the improvement of college students' entrepreneurial ability, entrepreneurship education and incentive policy formulation:

The Mobile Internet, big data and artificial intelligence technologies are rapidly changing the way entrepreneurs search, absorb and share information, as well as their cognitive framework and judgment of entrepreneurial opportunities. College students should reduce ineffective network activities and use various social media platforms to obtain business information, understand market dynamics, learn entrepreneurial skills and expand social networks, which is an effective way to improve the ability to recognize entrepreneurial opportunities and their awareness of entrepreneurship.

Priori knowledge is indispensable to the recognition of entrepreneurial opportunities. To find or create new market opportunities, entrepreneurs must have a matching knowledge background. Solid professional knowledge is the key to the success of college students' entrepreneurship. It is not advisable to over advertise and imitate entrepreneurs who "drop out to start a business". Empirical analysis shows that entrepreneurs who do not graduate from university have a higher probability of success than those who graduate from university. For college students who lack life experience, it is more likely to succeed in identifying entrepreneurial opportunities based on professional knowledge background.

The current entrepreneurship education in schools is "forcing students to learn", which stems from the fact that the teaching content and methods are single, and the teachers, lacking entrepreneurial experience, can only learn from the book, which is seriously out of touch with the actual business activities. Make full use of social media to establish entrepreneurship knowledge dissemination platform, invite entrepreneurs to participate in the development of training plans to increase the practicality of courses, so as to effectively make up for the shortcomings of traditional classroom teaching.

Stimulating entrepreneurial willingness and enhancing entrepreneurial alertness are the motivations for college students to recognize entrepreneurial opportunities. The government's entrepreneurial support policies for college students and entrepreneurship competitions can create a good entrepreneurial atmosphere. However, unfortunately, due to the high application and review threshold, few college students can enjoy preferential policies, and it is difficult for the winners of the entrepreneurship competition to continue to develop business opportunities. The entrepreneurial incentive policies for college students should expand their scope and provide precise support, such as rent, tax or technical services and other preferential policies, so as to explore more potential college students entrepreneurs.

Social capital is the key external factor to the success of entrepreneurship, which reflects the entrepreneurs' ability to organize resources. The process of college students developing entrepreneurial opportunities is the process of their own social capital reconstruction. Through school-enterprise alliances, virtual entrepreneurial groups, and participation in social practice, more college students are allowed to participate in business activities, so as to get to know people from different backgrounds and different business fields, and to enrich the social relationship network, which is a necessary way to improve the success rate of college students' recognition and development of entrepreneurial opportunities. 


\section{References}

Aldrich, H. E., \& Cliff, J. E. (2003). The pervasive effects of family on entrepreneurship: toward a family embeddedness perspective. Journal of Business Venturing, 18(5), 573-596. https://doi.org/10.1016/S0883-9026(03)00011-9

Alvarez, S. A., \& Barney, J. B. (2007). Discovery and creation: alternative theories of entrepreneurial action. Strategic Entrepreneurship Journal, 1(1-2), 11-26. https://doi.org/10.1002/sej.4

Anokhin, S., Troutt, M. D., Wincent, J., \& Brandyberry, A. A. (2010). Measuring Arbitrage Opportunities. Organizational Research Methods, 13(1), 55-66. https://doi.org/10.1177/1094428109337541

Ayalew, M. M., \& Zeleke, S. A. (2018). Modeling the impact of entrepreneurial attitude on self-employment intention among engineering students in Ethiopia. Journal of Innovation and Entrepreneurship, 7(1) https://doi.org/10.1186/s13731-018-0088-1

Baron, R. A., \& Ensley, M. D. (2006). Opportunity Recognition as the Detection of Meaningful Patterns: Evidence from Comparisons of Novice and Experienced Entrepreneurs. Management Science, 52(9), 1331-1344. https://doi.org/10.1287/mnsc.1060.0538

Baron, R. A., \& Tang, J. (2011). The role of entrepreneurs in firm-level innovation: Joint effects of positive affect, creativity, and environmental dynamism. Journal of Business Venturing, 26(1), 49-60. https://doi.org/10.1016/j.jbusvent.2009.06.002

Bin, P., Wang, L., Wang, Y., \& Hu, R. (2018). Differences in entrepreneurial intentions of Chinese college students: evidence from an Oaxaca-Blinder decomposition. Entrepreneurship Education, 1(1-4), 27-40. https://doi.org/10.1007/s41959-018-0008-5

Blank, T. H. (2020). When incubator resources are crucial: survival chances of student startups operating in an academic incubator. The Journal of Technology Transfer, (2), 1-24. https://doi.org/10.1007/s10961-020-09831-4

Bocconcelli, R., Cioppi, M., \& Pagano, A. (2017). Social media as a resource in SMEs' sales process. The Journal of business \& industrial marketing, 32(5), 693-709. https://doi.org/10.1108/JBIM-11-2014-0244

Breznitz, S. M., \& Zhang, Q. (2019). Fostering the growth of student start-ups from university accelerators: an entrepreneurial ecosystem perspective. Industrial And Corporate Change, 28(4), 855-873. https://doi.org/10.1093/icc/dtz033

Buenstorf, G., Geissler, M., \& Krabel, S. (2016). Locations of labor market entry by German university graduates: is (regional) beauty in the eye of the beholder? Review of Regional Research, 36(1), 29-49. https://doi.org/10.1007/s10037-015-0102-Z

Cliff, J. E., Jennings, P. D., \& Greenwood, R. (2006). New to the game and questioning the rules: The experiences and beliefs of founders who start imitative versus innovative firms. Journal of Business Venturing, 21(5), 633-663. https://doi.org/10.1016/j.jbusvent.2005.02.010

Cooper, S. Y., \& Park, J. S. (2008). Technology Innovation in New, Entrepreneurial High-technology Ventures The Impact of 'Incubator' Organizations on Opportunity Recognition and. International Small Business Journal-Researching Entrepreneurship, 26(1), 27-56. https://doi.org/10.1177/0266242607084658

De Carolis, D. M., \& Saparito, P. (2006). Social Capital, Cognition, and Entrepreneurial Opportunities: A Theoretical Framework. Entrepreneurship Theory and Practice, $30(1), \quad$ https://doi.org/10.1111/j.1540-6520.2006.00109.x

Dohse, D., \& Walter, S. G. (2012). Knowledge context and entrepreneurial intentions among students. Small Business Economics, 39(4), 877-895. https://doi.org/10.1007/s11187-011-9324-9

Dong, Y., \& Zhang, Z. (2019). An Analysis of Chinese Entrepreneurs' Entrepreneurial Opportunity Identification. Review of Economy and Management, 35(215(06)), 59-69. http://doi.org/10.13962/j.cnki.37-1486/f.2019.06.006

Drummond, C., McGrath, H., \& O'Toole, T. (2018). The impact of social media on resource mobilisation in entrepreneurial firms. $\quad$ Industrial Marketing $\quad$ Management, $\quad$ 70, https://doi.org/10.1016/j.indmarman.2017.05.009

Fernandes, S., Belo, A., \& Castela, G. (2016). Social network enterprise behaviors and patterns in SMEs: Lessons from a Portuguese local community centered around the tourism industry. Technology in Society, 44, 15-22. https://doi.org/10.1016/j.techsoc.2015.11.004

Hao, X., Tan, W., \& Xu, L. (2019). The Mechanism of Counterfactual Thinking on Entrepreneurial Opportunity 
Identification: A Case Study Based on College Students' Entrepreneurship] Science and Technology Management Research, 39(22), 106-113.

Huang, J. (2016). Identification of Opportunities on College Students Founding Micro-enterprises in Rural and Small town. Science and Technology Management Research, 36(09), 192-197.

Kirzner, I. (1979). Perception, opportunity, and profit $\therefore$ University of Chicago Press.

Kuhn, K., Galloway, T., \& Collins-Williams, M. (2016). Near, far, and online: small business owners' advice-seeking from peers. Journal of small business and enterprise development, 23(1), 189-206. https://doi.org/10.1108/JSBED-03-2015-0037

Liu, Z., Ding, F., Xiao, Y., \& Cui, L. (2019). Research on the Mechanism of Opportunity Recognition and Development of Social Entrepreneurship Based on the Theory of Resource Bricolage. Chinese Journal of Management, 16(07), 1006-1015.

Mack, E. A., Marie-Pierre, L., \& Redican, K. (2016). Entrepreneurs' use of internet and social media applications. Telecommunications Policy, 41(2), 120-139. https://doi.org/10.1016/j.telpol.2016.12.001

Mary George, N., Parida, V., Lahti, T., \& Wincent, J. (2016). A systematic literature review of entrepreneurial opportunity recognition: insights on influencing factors. International Entrepreneurship and Management Journal, 12(2), 309-350. https://doi.org/10.1007/s11365-014-0347-y

Mohajerani, A., Baptista, J., \& Nandhakumar, J. (2015). Exploring the role of social media in importing logics across social contexts: The case of IT SMEs in Iran. Technological Forecasting and Social Change, 95, 16-31. https://doi.org/10.1016/j.techfore.2014.06.008

Motoyama, Y., Goetz, S., \& Han, Y. (2018). Where do entrepreneurs get information An analysis of twitter-following patterns. Journal of Small Business \& Entrepreneurship, 1-22. https://doi.org/10.1080/08276331.2018.1435187

Quinton, S., \& Wilson, D. (2016). Tensions and ties in social media networks: Towards a model of understanding business relationship development and business performance enhancement through the use of LinkedIn. INDUSTRIAL MARKETING MANAGEMENT, 54, 15-24. https://doi.org/10.1016/j.indmarman.2015.12.001

Reim, W., Parida, V., \& Örtqvist, D. (2014). Product-Service Systems (PSS) business models and tactics - a systematic literature review. Journal of Cleaner Production, 97, 61-75. https://doi.org/10.1016/j.jclepro.2014.07.003

Reiter, L., McHaney, R., \& Connell, K. Y. H. (2017). Social media influence on purchase intentions: instrument validation. International Journal of Web Based Communities, 13(1), 54. https://doi.org/10.1504/IJWBC.2017.082719

RezaeiZadeh, M., Hogan, M., O Reilly, J., Cunningham, J., \& Murphy, E. (2017). Core entrepreneurial competencies and their interdependencies: insights from a study of Irish and Iranian entrepreneurs, university students and academics. International Entrepreneurship and Management Journal, 13(1), 35-73. https://doi.org/10.1007/s11365-016-0390-y

Schumpeter, J. (1934). The theory of economic development. Cambridge: Harvard University Press.

Shane, S. (2000). Prior Knowledge and the Discovery of Entrepreneurial Opportunities. Organization Science, 11(4), 448-469. https://doi.org/10.1287/orsc.11.4.448.14602

Smith, C., Smith, J. B., \& Shaw, E. (2017). Embracing digital networks: Entrepreneurs' social capital online. Journal of Business Venturing, 32(1), 18-34. https://doi.org/10.1016/j.jbusvent.2016.10.003

Sun, Y., \& Ding, Y. (2018). Entrepreneurial Orientation, External Knowledge Acquisition and Entrepreneurial Opportunity Recognition. Research on Economics and Managment, 39(05), 130-144.

Ucbasaran, D., Wright, M., \& Westhead, P. (2003). A longitudinal study of habitual entrepreneurs: starters and acquirers. Entrepreneurship and Regional Development, 15(3), 207-228. https://doi.org/10.1080/08985620210145009

Wang, F., \& Yao, G. (2014). On Improving College Students' Ability to Recognize Opportunities in Starting an Undertaking. Journal of National Academy of Education Administration, (08), 57-60.

Wang, F., Mack, E. A., \& Maciewjewski, R. (2016). Analyzing Entrepreneurial Social Networks with Big Data. Annals of the American Association of Geographers, 107(1), 130-150. https://doi.org/10.1080/24694452.2016.1222263

Wang, F., Xu, Z., \& Gu, Y. (2015). The Influence Of Social Network On College Students' Entre - preneurial Opportunity Identification. Heilongjiang Researches on Higher Education, (09), 145-148.

Wang, P., \& Lu, Q. (2015). The Influence of the University Students' Entrepreneurial Alertness, Prior Knowledge and 
Entrepreneurial Experiences on Entrepreneurial Opportunity Recognition. Journal of Psychological Science, $38(01), 160-165$.

Yu, W., \& Li, W. (2020). Is Online Social Network Interaction Helpful for the Entrepreneurial Opportunities Recognition-Based on the two dimensional Perspective of network trust. Economic Theory and Business Management, (05), 86-99.

Zhang, H., \& Ge, B. (2014). A Review of the Literature of Entrepreneurial Opportunity Identification and the Construction of an Integrated Model. Foreign Economics \& Management, 36(04), 15-24.

Zhang, X., Qi, W., \& Li, Z. (2017). Research on the influencing mechanism of entrepreneur experience on the entrepreneurial opportunity identification. Studies in Science of Science, 35(3), 419-427. http://doi.org/10.3969/j.issn.1003-2053.2017.03.013

Zhang, X., Zhang, X., \& Le, Y. (2018). Research on the Impact of Network Social Information Dissemination on College Students' Entrepreneurial Opportunity Identification. Research on Library Science, (21), 55-57.

\section{Copyrights}

Copyright for this article is retained by the author(s), with first publication rights granted to the journal.

This is an open-access article distributed under the terms and conditions of the Creative Commons Attribution license which permits unrestricted use, distribution, and reproduction in any medium, provided the original work is properly cited. 